\title{
DESAIN DAN VALIDITAS LEMBAR KERJA PESERTA DIDIK BERDASARKAN KERAGAMAN IKAN DI SUNGAI PURA BENGKULU UTARA
}

\author{
Amalia Hafifah ${ }^{1 *}$, Kasrina Kasrina ${ }^{1}$, dan Abdul Rahman Singkam ${ }^{1}$ \\ ${ }^{1}$ Program Studi Pendidikan Biologi Fakultas Keguruan dan Ilmu Pendidikan, Universitas Bengkulu \\ Email: amaliahafifah07@gmail.com
}

\begin{abstract}
Abstrak
Penelitian ini bertujuan untuk mengetahui hasil uji validitas dan uji keterbacaan Lembar Kerja Peserta Didik (LKPD) materi keanekaragaman hayati berdasarkan hasil penelitian keanekaragaman jenis ikan di Sungai Pura Bengkulu Utara. Teknik pengumpulan data pada penelitian ini adalah angket (kuisioner). Instrumen penelitian yang digunakan adalah lembar angket uji keterbacaan dan uji validitas. Instrumen yang digunakan adalah lembar angket (kuisioner) untuk tiga orang validator (dua orang Dosen Program Studi Pendidikan Biologi dan guru Biologi SMA kelas X), dan lembar keterbacaan untuk peserta didik. LKPD yang disusun memperoleh kriteria sangat valid, dengan nilai $85,36 \%$ dari para validator, dan juga dinilai sangat layak dengan nilai 94,32\% dalam uji keterbacaan oleh 26 orang peserta didik di SMAN 2 Bengkulu Utara. Hasil validasi dan uji keterbacaan ini menunjukkan bahwa LKPD yang disusun layak digunakan sebagai bahan ajar materi keanekaragaman hayati kelas $X$ tingkat SMA.
\end{abstract}

Kata Kunci : Lembar Kerja Peserta Didik, Keanekaragaman Hayati, Ikan Air Tawar

\begin{abstract}
This research aims to determine the results of the validity test and the readability test of the students Worksheets (LKPD) of biodiversity material based on the results of the research of fish types in the north of Bengkulu Pura River. The technique of collecting data on this research is a questionnaire. The research instruments used are legibility test and validity test instruments used is a questionnaire for three persons validators (two lecturers of Biology education study Program and grade X High School biology teachers), and Readability sheets for learners. The compiled LKPD has a very valid criterion, with a value of $92.2 \%$ of the validators, and is also highly rated with a value of $95.32 \%$ in legibility tests by 26 students at the SMAN 2 of Bengkulu North. The results of this validation and legibility test show that the LKPD was ordered to be used as the teaching material of grade $X$ high school level biodiversity.
\end{abstract}

Keywords: Student Worksheets, Biodiversity, Freshwater Fish

\section{PENDAHULUAN}

Provinsi Bengkulu memiliki perairan tawar yang sangat luas, terdiri dari danau, rawa, dan sungai. Luas danau di Provinsi Bengkulu mencapai $10.680 \mathrm{Ha}$. Provinsi Bengkulu juga memiliki sekitar 63 daerah aliran sungai. Beberapa sungai terpanjang antara lain: Sungai Ketahun di Bengkulu Utara sepanjang 122,75 km, Sungai Nasal di Kabupaten Kaur sepanjang 61,25 km, dan sungai kecil lainnya seperti Sungai Jenggalu sepanjang 25 km dan Sungai Pura (Air Besi) sepanjang 16.25 (Lingkungan Hidup Provinsi Bengkulu, 2014).

Sumber daya perairan tawar yang luas ini memiliki potensi pemanfaatan yang tinggi. Sumber daya perairan ini dapat dimanfaatkan sebagai sarana dan prasarana bagi penduduk yang berada di dekat sumberdaya perairan ini. Pemanfaatan ini dapat berupa sebagai irigasi persawahan, sumber air, pembangkit listrik, objek wisata, mandi cuci kakus, dan penunjang 
perekonomian. Salah satu potensi terbesar lainnya adalah sebagai tempat hidup berbagai biota air seperti udang dan ikan.

Keragaman biota air tawar ini dapat dimanfaatkan sebagai sumber belajar di sekolah. Sumber belajar adalah segala sesuatu yang mendukung terjadinya proses pembelajaran termasuk sistem pelayanan bahan pembelajaran, dan lingkungan yang digunakan secara terpisah maupun kombinasi, sehingga mempermudah anak didik mencapai kompetensi yang harus dicapainya (AECT, 1976). Pemanfaatan lingkungan sebagai sumber belajar merupakan salah satu cara untuk mendekatkan peserta didik pada realitas objektif (Hendrawati, 2013). Salah satu bentuk bahan ajar yang dapat dibuat dengan memanfaatkan lingkungan sekitar adalah Lembar Kerja Peserta Didik (LKPD).

LKPD merupakan salah satu sumber belajar dan media pembelajaran yang dapat membantu peserta didik maupun guru dalam proses pembelajaran (Trianto, 2012). Hal ini didukung oleh Yasir (2013), menurutnya LKPD itu sendiri berfungsi sebagai bahan ajar yang memberikan kesempatan kepada peserta didik untuk belajar secara mandiri. Proses pembelajaran dengan menggunakan LKPD IPA berbasis lingkungan dapat meningkatkan motivasi belajar peserta didik antara ketiga kegiatan dari hasil One Way Anova. Berdasarkan hasil paired $t$ test peningkatan motivasi belajar peserta didik (Hanny, 2014). Namun, berdasarkan observasi di SMAN 2 Bengkulu Utara terlihat diketahui saat ini guru lebih banyak memilih menggunakan LKPD buatan penerbit dikarenakan lebih praktis.

Berdasarkan permasalahan di atas, peneliti tertarik untuk memanfaatkan keragaman ikan air tawar di Sungai Pura
Bengkulu Utara menjadi LKPD berbasis lingkungan sekitar. LKPD tersebut diaplikasikan pada materi keanekaragaman hayati kelas $\mathrm{X}$, dengan Kompetensi Dasar (KD) 3.2 dan 4.2. KD 3.2 mengenai menganalisis berbagai tingkat keanekaragaman hayati (tingkat gen, jenis dan ekosistem) di Indonesia beserta ancaman dan pelestariannya. KD 4.2 menyajikan hasil observassi berbagai tingkat keanekaragaman hayati di Indonesia dan usulan upaya pelestariannya. Sebelum diaplikasikan, LKPD ini diuji validasi oleh ahli dan peserta didik serta diuji coba skala terbatas di Sekolah Menengah Atas (SMA) Negeri 2 Bengkulu Utara.

\section{METODE}

Metode yang digunakan dalam penelitian ini adalah metode penelitian dan pengembangan (Research and Develoment) dengan langkah-langkah mengadopsi dari Sugiyono (2016). Dari 10 langkah penelitian dan pengembangan Sugiyono (2016), peneliti menggunakan hanya 7 langkah. Adapun langkah yang digunakan peneliti yaitu: potensi dan masalah, pengumpulan data, validasi desain, uji skala terbatas, revisi produk, uji keterbacaan, dan revisi desain. Penelitian ini dilakukan pada Januari 2019 sampai Maret 2019. Pengambilan sampel dilakukan di perairan Sungai Pura, Desa Talang Ginting dan Desa Kertapati Kecamatan Air Besi Kabupaten Bengkulu Utara. Subjek uji coba skala terbatas dalam penelitian ini adalah peserta didik kelas $X$ MIPA3 SMA Negeri 2 Bengkulu Utara. Teknik pengumpulan data dalam penelitian ini menggunakan lembar angket (kuesioner) yang terdiri atas angket uji kelayakan untuk validator (ahli materi, Data uji validasi dan uji keterbacaan yang terkumpul dianalisis secara deskriptif kuantitatif. Angka hasil uji 
yang diperoleh diubah ke dalam persentase kelayakan dengan rumus:

$\frac{\text { Jumlah Skor Lembar Validasi }}{\text { Skor Maksimal }} \times 100 \%$

Riduwan (2013).

Persentase skor yang didapatkan dari masing-masing validator kemudian dirataratakan dengan menggunakan rumus sebagai berikut: $X=\frac{\sum A}{n}$

Keterangan:

$\mathrm{X} \quad$ : Nilai rata-rata validator

$\sum A \quad$ : Jumlah skor yang didapatkan dari tiap validator

n : Jumlah validator

(Riduwan, 2013).

\section{HASIL DAN PEMBAHASAN}

Hasil yang didapatkan pada penelitian ini adalah hasil uji validasi oleh 3 orang validator dan uji keterbacaan oleh peserta didik. Hasil uji validasi disajikan dalam tabel 1. Hasil uji keterbacaan disajikan dalam tabel 2.

Tabel 1. Persentase Validasi LKPD Oleh Validator

\begin{tabular}{llll}
\hline No & \multicolumn{1}{c}{ Validator } & \multicolumn{1}{c}{$\begin{array}{c}\text { Nilai } \\
\text { Presentase }\end{array}$} & $\begin{array}{l}\text { Kriteria } \\
\text { Respon }\end{array}$ \\
\hline 1. & $\begin{array}{l}\text { Validator 1 (Ahli } \\
\text { Materi) }\end{array}$ & $84,44 \%$ & $\begin{array}{l}\text { Sangat } \\
\text { Layak }\end{array}$ \\
2. & $\begin{array}{l}\text { Validator 2 (Ahli } \\
\text { Media) }\end{array}$ & $85 \%$ & $\begin{array}{l}\text { Sangat } \\
\text { Layak }\end{array}$ \\
& $\begin{array}{l}\text { Validator } \\
\text { (Guru Biologi } \\
\text { SMA kelas X) }\end{array}$ & $86,66 \%$ & $\begin{array}{l}\text { Sangat } \\
\text { Layak }\end{array}$ \\
& & Sangat \\
Rata-rata presentase & $85,36 \%$ & Layak \\
\hline
\end{tabular}

Secara keseluruhan, desain LKPD ini dinilai sangat valid oleh validator dengan niai ratarata $85,36 \%$. Walaupun telah mendapatkan kriteria sangat layak LKPD yang sudah didesain mendapatkan beberapa saran dari validator. Adapun saran yang diberikan validator adalah sebagai berikut: 1). Pada bagian cover lebih baik ditambahkan tulisan UNIB 2019 untuk mengetahui tahun pembuatan LKPD ini; 2). Pada tujuan LKPD sebaiknya lebih disesuaikan dengan KD dari materi; 3). Pada bagian pertanyaan sebaiknya lebih disesuaikan dengan tabel pengamatan; 4). Pada penggunaan namanama ilmiah sesuai dengan kaidah penulisan ilmiah; dan 5). Pada bagian kesimpulan peserta didik diberi panduan kesimpulan.

Berdasarkan saran dari validator dan peserta didik, maka dilakukan perbaikan sebagai berikut:

a. Halaman depan (cover) memiliki komponen tulisan LKPD, judul LKPD, kelompok, kelas, hari/tanggal, nama anggota, nama penyusun, logo Universitas Bengkulu, Fakultas keguruan dan ilmu pendidikan UNIB 2019 yang menunjukan bahwa LKPD tersebut berada dalam naungan fakultas di Universitas Bengkulu pada tahun 2019. Halaman cover dibuat semenarik mungkin dan dilengkapi dengan gambar Sungai Pura dan dua gambar ikan yang mewakili jenis-jenis ikan di perairan Sungai Pura Bengkulu Utara. Cover sebelum dan sesudah revisi dapat dilihat pada Gambar 1.
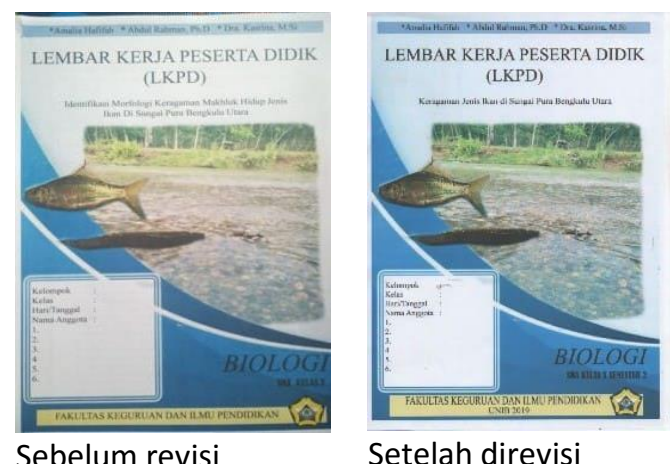

Setelah direvisi

Gambar 1. Cover LKPD 
b. Kompetensi dasar pasa materi keanekaragaman hayati kelas $\mathrm{X}$ ini menganalisis berbagai tingkat keanekaragaman hayati di Indonesia beserta ancaman dan pelestariannya. Kompetensi dasar ini digunakan sebagai acuan pada tujuan kegiatan. Kompetensi Dasar sebelum dan sesudah revisi dapat dilihat pada (Gambar 2)

c. Tujuan kegiatan dalam LKPD ini terdiri dari dua tujuan yaitu (1) peserta didik mampu mengetahui struktur morfologi ikan untuk menentukan keanekaragaman tingkat jenis, (2) peserta didik mampu mendeskripsikan ciri-ciri morfologi ikan antar spesies yang berbeda untuk menentukan keanekaragaman tingkat jenis. Tujuan kegiatan sebelum dan sesudah revisi dapat dilihat pada (Gambar 2).

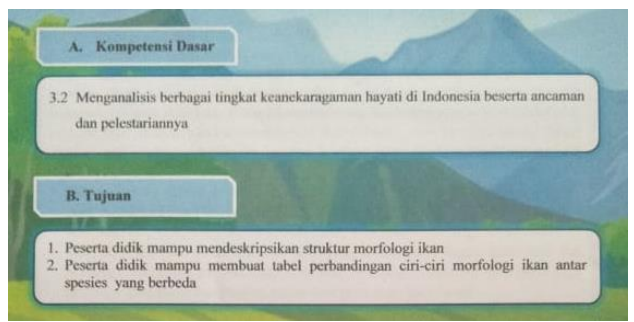

Sebelum revisi

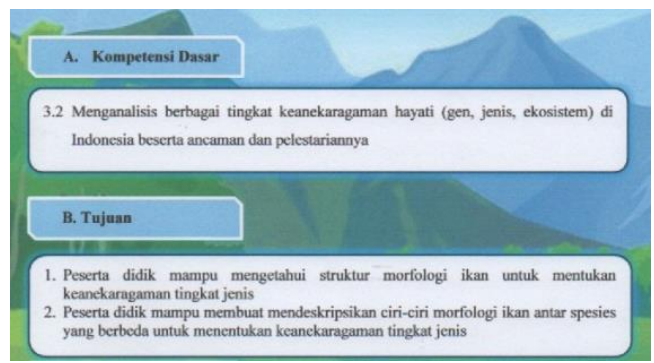

Setelah revisi

Gambar 2. Kompetensi Dasar (KD), dan Tujuan

d. Ringkasan materi pada LKPD pada bagian satu meliputi: pengertian keanekaragaman hayati dan tiga tingkatan keanekaragaman hayati beserta contohnya. Bagian dua keanekaraman jenis ikan meliputi pengertian ikan dan ciri-ciri struktur morfologi ikan beserta tipenya. Ringkasan materi sebelum dan sesudah revisi dapat dilihat pada Gambar 3.
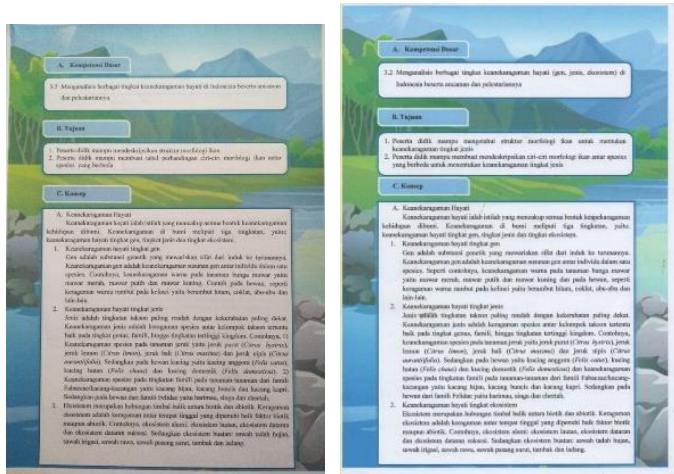

Sebelum revisi
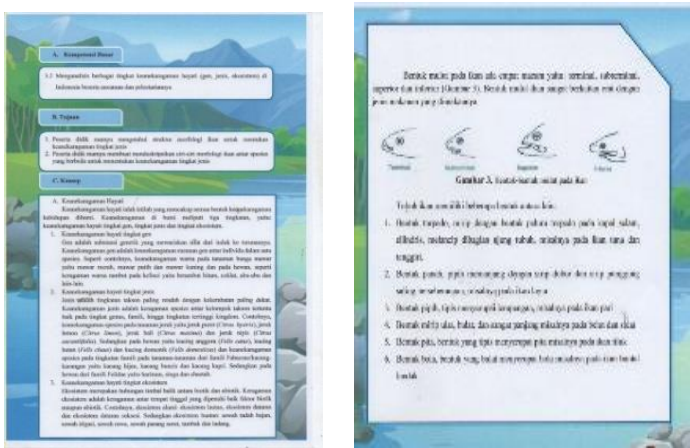

Setelah revisi

Gambar 3. Konsep/Ringkasan Materi

e. Alat, bahan dan langkah kerja. Alat dan bahan yang digunakan mencakup seluruh kegiatan. Langkah kerja pada LKPD dibuat sesuai kegiatan yang dilakukan oleh peserta didik dengan melihat awetan ikan yang ada di dalam kotak sampel besar yang disediakan. Langkah kerja bersifat mengarahkan kegiatan peserta didik pada saat melakukan praktikum dilengkapi dengan gambar kotak sampel besar dan ikan, ciri-ciri morfologi dari ikan meliputi bentuk tubuh, letak mulut, sirip (punggung, ekor, dada, perut, dubur) serta jumlah duri keras dan duri lunak pada setiap bagian sirip. Alat, 
bahan dan langkah kerja sebelum dan sesudah revisi dapat dilihat pada Gambar 4.

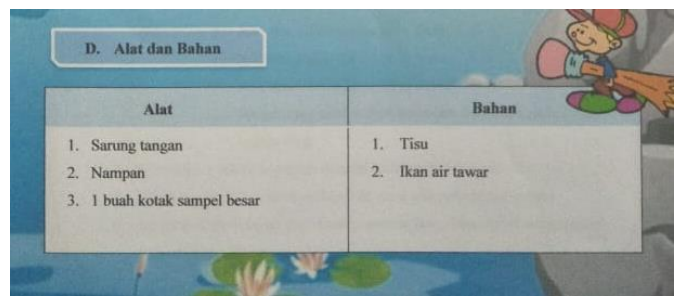

Sebelum revisi

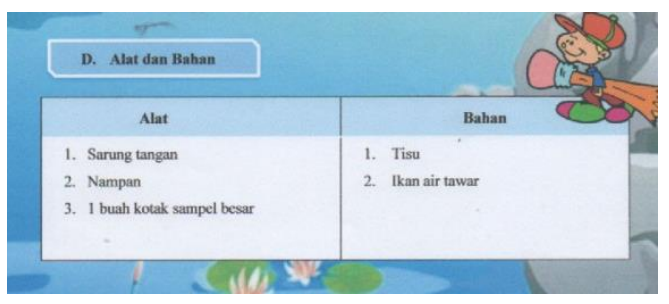

Sesudah revisi

Gambar 4. Alat dan Bahan LKPD

f. Tabel pengamatan ditampilkan dalam bentuk tabel dan awetan ikan yang harus diindentifikasi ciri-ciri morfologinya untuk mengelompokan spesies-spesies yang sama. Tabel pengamatan sebelum dan sesudah revisi dapat dilihat pada Gambar 5.

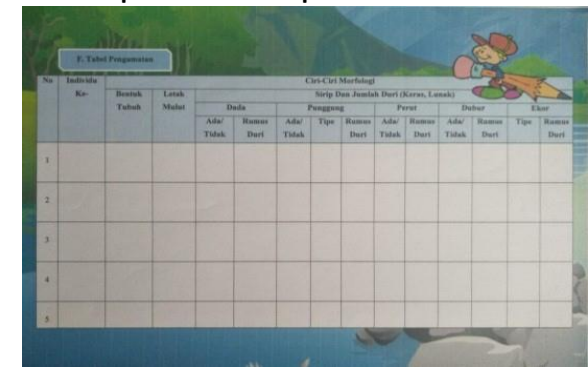

Sebelum revisi

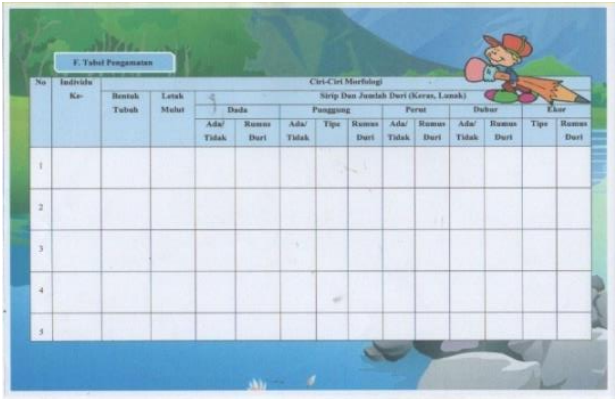

Sesudah revisi

Gambar 5. Langkah Kerja LKPD g. Pertanyaan LKPD dibuat berdasarkan tabel pengamatan dan diskusi peserta didik untuk menjawab pertanyaanpertanyaan yang sudah disediakan. Pertanyaan LKPD sebelum dan sesudah revisi dapat dilihat pada Gambar 6.

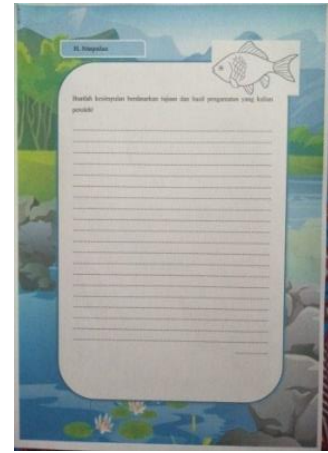

Sebelum revisi

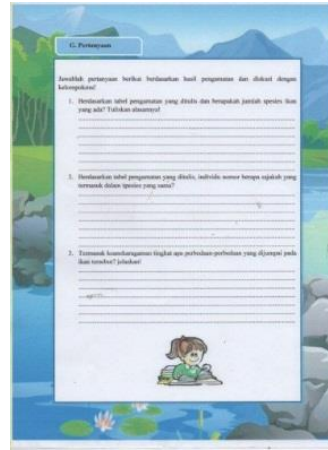

Sesudah revisi
Gambar 6. Pertanyaan LKPD

h. Kesimpulan disajikan kotak kesimpulan agar menarik peserta didik dan untuk mengisi kesimpulan diberikan panduan agar memudahkan peserta didik. Kesimpulan sebelum dan sesudah revisi dapat dilihat pada Gambar 7.

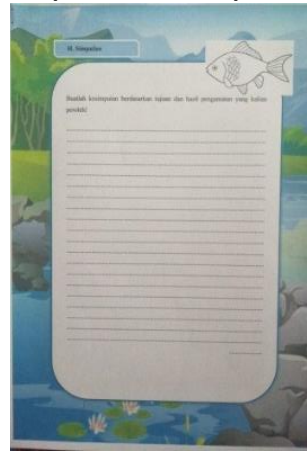

Sebelum revisi

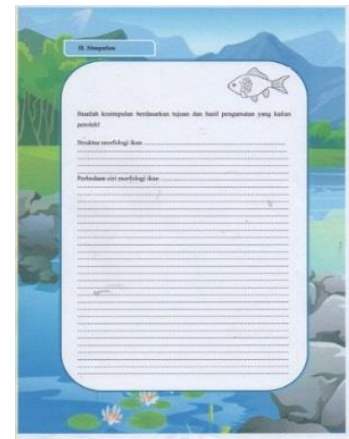

Sesudah revisi
Gambar 7. Kesimpulan LKPD

LKPD yang diberikan saran dari validator kemudian revisi, setelah direvisi dilanjutkan dengan uji keterbacaan LKPD pada siswa kelas. Hasil uji keterbacaan dapat dilihat pada Tabel 4: 
Tabel 4. Uji Keterbacaan Peserta Didik

\begin{tabular}{clcc}
\hline No & \multicolumn{1}{c}{ Pernyataan } & Nilai Presentase & Kriteria \\
\hline 1. & $\begin{array}{l}\text { Struktur LKPD disusun secara sistematis/urut } \\
\text { sehingga saya mudah memahaminya }\end{array}$ & $88,46 \%$ & Sangat Baik \\
2. & $\begin{array}{l}\text { Kegiatan yang disajikan dalam LKPD mempunyai } \\
\text { tujuan yang jelas }\end{array}$ & $100 \%$ & Sangat Baik \\
3. $\begin{array}{l}\text { Kegiatan yang disajikan dalam LKPD dapat } \\
\text { merangsang keingintahuan saya }\end{array}$ & $92,30 \%$ & Sangat Baik \\
4. $\begin{array}{l}\text { Penampilan LKPD membuat saya tertarik untuk } \\
\text { mengerjakannya }\end{array}$ & $92,30 \%$ & Sangat Baik \\
5. $\begin{array}{l}\text { Pengajian LKPD dilengkapi dengan gambar dan } \\
\text { ilustrasi sehingga membantu saya memahami } \\
\text { materi. }\end{array}$ & $96,15 \%$ & Sangat Baik \\
6. Susunan kalimat yang disajikan jelas, sederhana, & $100 \%$ & Sangat Baik \\
dan mudah saya mengerti & Bahasa yang digunakan dapat saya pahami & Sangat Baik \\
8. Bahasa yang disajikan sesuai dengan tingkat \\
perkembangan saya
\end{tabular}

*Jumlah peserta didik 26 orang

Hasil uji keterbacaan memperlihatkan setiap butir mendapatkan penilaian sangat baik. LKPD hasil revisi mendapatkan skor rata-rata $94,23 \%$. Hal ini menunjukkan LKPD yang telah direvisi dinilai layak dalam uji keterbacaan oleh peserta didik kelas $X$ MIPA3 SMAN 2 Bengkulu Utara. Berdasarkan hasil tersebut dapat dikatakan bahwa LKPD hasil revisi layak untuk digunakan.

LKPD penerbit maupun LKPD yang dikembangkan peneliti memiliki kekurangan dan kelebihan. LKPD penerbit memiliki beberapa keunggulan dan kelemahan. Keunggulan dari LKPD penerbit yaitu LKPD lebih praktis, dikarenakan telah tersedia dan guru bisa langsung mengunakannya. Sedangkan kelemahan dari LKPD penerbit yaitu dilihat dari aspek materi dan komponen penyusunan kurang sesuai dengan ketentuan pembuatan LKPD yang sebenarnya yaitu tidak mempunyai Kompetensi Dasar (KD), materi, dan kesimpulan. LKPD penerbit memiliki tampilan yang terlalu sederhana. LKPD penerbit hanya berisikan materi tumbuhan, dan LKPD penerbit tidak dikaitkan dengan lingkungan sekitar.

LKPD hasil penelitian ini memiliki beberapa keunggulan dan kelemahan. Keunggulan dari LKPD pengembangan dilihat dari desain tampilan yang lebih menarik peserta didik karena disertai dengan gambar. Elwi, dkk (2017) menyatakan, bahan ajar yang menarik dan memungkinkan peserta didik utuk lebih 
bersemangat dalam proses pembelajaran. LKPD hasil pengembangan ini dapat dikerjakan mandiri karena dilengkapi dengan petunjuk setiap kegiatannya. Materi pada LKPD lebih disesuaikan dengan potensi lingkungan sekitar yang meningkatkan minat peserta didik untuk sadar pentingnya menjaga lingkungan sekitar. Penelitian Rarasandy (2013), menyimpulkan pembelajaran yang mengarah pada penanaman karakter peduli lingkungan dapat meningkatkan kepedulian siswa terhadap lingkungan dan penguasaan konsep siswa pada materi pengelolaan lingkungan. Penggunaan lingkungan sebagai media dalam pembelajaran berupa LKPD membuat peserta didik lebih mengetahui secara nyata objek studi. Hal ini didukung oleh pernyataan Syamsudduh dan Muh (2012) yang menyatakan memanfaatkan lingkungan sebagai media dalam belajar memberikan pengalaman real kepada siswa pembelajaran lebih konkrit. Hasil pengembangan disusun sesuai komponen dari Depdiknas (2008). Soal LKPD sudah mencapai Kompetensi Dasar 3.2 dan 4.2. menganalisis berbagai tingkat keanekaragaman hayati (tingkat gen, jenis dan ekosistem) di Indonesia beserta ancaman dan pelestariannya. 4.2 menyajikan hasil observasi berbagai tingkat keanekaragaman hayati di Indonesia dan usulan upaya pelestariannya. Sedangkan kekurangan LKPD pengembangan, bahan ajar yang dikembangkan masih terbatas hanya pada materi keanekaragaman hayati tingkat jenis.

Hasil penelitian yang didapatkan menunjukkan LKPD hasil pengembangan memiliki kesesuaian dengan penelitianpenelitian sebelumnya. Penelitian Fajri (2018), menyatakan hasil desain pengembangan LKPD materi Vertebrata kelas $\mathrm{X}$ berdasarkan inventarisasi ikan laut mendapatkan skor uji keterbacaan sebesar 96 kategori sangat layak dan mendapat skor uji validitas memperoleh skor 91. Penelitian Rahayu (2017) juga menyimpulkan, LKS hasil pengembangan berdasarkan eksplorasi tanaman obat pada materi keanekaragaman hayati mendapatkan kategori sangat layak dari validator, dan layak digunakan dalam pembelajaran biologi. Selain itu Penelitian Pengembangan LKPD berdasarkan identifikasi Mangrove oleh Lorena (2018) mendapatkan kesimpulan bahwa LKPD yang dikembangkan sangat valid dan sangat layak digunakan sebagai bahan ajar materi keanekaragaman hayati.

\section{PENUTUP}

\section{Simpulan}

Lembar Kerja Peserta Didik (LKPD) hasil pengembangan dinyatakan sangat layak diujicobakan kepada peserta didik oleh para ahli dengan rata-rata nilai $85,36 \%$. Desain LKPD yang dikembangkan dinilai sangat baik $94,23 \%$ berdasarkan hasil uji keterbacaan.

\section{Saran}

Perlu dilakukan uji coba dengan skala yang lebih luas melibatkan sampel peserta didik dan sekolah yang lebih banyak untuk melihat efeketifitas LKPD yang dikembangkan.

\section{DAFTAR PUSTAKA}

AECT (Association for Educational Communication and Technology). Evaluating Media Programs District and School, Washington, D.C : The Association, 1976. 
Depdiknas. 2008. Panduan Pengambangan Bahan Ajar. Jakarta: Direktorat Pembinaan Sekolah Menengah Atas.

Fajri, A., Singkam, A. R., dan Ariefa, P. Y. 2018. Pengembangan Lembar Kerja Peserta didik Materi Vertebrata Kelas $\mathrm{X}$ Berdasarkan Inventarisasi Ikan Laut. Jurnal Pendidikan dan Pembelajaran Biologi 2 (2): 52-57.

Hendrawati, E. Pengaruh Pemanfaatan Lingkungan Sebagai Sumber Belajar Melalui Metode Inkuiri Terhadap Hasil Belajar Siswa SDN 1 Sribit Delanggu pada Pelajaran IPS. Jurnal Pendidikan 2 (1): 59-70.

Henny. 2014. Pengembangan LKPD IPA Berbasis Lingkungan untuk Meningkatkan Motivasi Belajar dan Kerjasama Peserta Didik SMP. Thesis. UNY.

Lingkungan Hidup Provinsi Bengkulu. 2014 Lorena, M., Kasrina, K., Ariefa. P. Y. 2018. Pengembangan LKPD Model Discovery Learning Berdasarkan Identifikasi Mangrove di TWA Pantai Panjang. Jurnal Pendidikan Dan Pembelajaran Biologi 3 (1): 59-66.

Rahayu, H., Ariefa, P.Y., dan Irdam, I. 2017. Pengembangan LKS Berdasarkan Eksplorasi Tanaman Obat Suku Pekal pada Materi Keanekaragaman Hayati. Jurnal Pendidikan Dan Pembelajaran Biologi 1 (1): 37-45.

Rarasandy, L., Dyah, R.I., dan Kukuh, S. 2013. Pembelajaran Biologi Mengarah pada Penanaman Karakter Peduli Lingkungan pada Materi Pengelolaan Lingkungan. Lembaran IImu Kependidikan 42 (2): 129-136.
Riduwan. 2013. Skala Pengukuran VariabelVariabel Penelitian. Bandung: Alfabeta

Sugiono. 2016. Metode Penelitian Pendidikan (Pendekatan Kuantitatif, Kualitatif, dan R\&D). Bandung: Alfabet

Syamsudduha dan Muh, R. 2012. Penggunaan Lingkungan Sekolah sebagai Sumber Belajar dalam Meningkatkan Hasil Belajar Biologi. Lentera pendidikan 15 (1): 18-31.

Trianto. 2010. Pengantar Penelitian Pendidikan Bagi Pengembangan Profesi Pendidikan \& Tenaga Kependidikan. Jakarta: Prenada Media Group

Elwi, L. C. Festiyed, F., Dan Djusmaini, D. 2017. Pembuatan Lembar Kerja Peserta Didik (LKPD) Multimedia Interaktif Menggunakan Course Lab Berbasis Pendekatan Saintifik Pada Pembelajaran Fisika Kelas X SMA/MA. Pillar of Physics Education 9 () : 97104.

Yasir, M., Susantini, E., dan Isnawati. 2013. Pengembangan lembar kerja Siswa (LKS) Berbasis Stretegi Belajar metakognitif untuk meningkatkan hasil belajar siswa pada materi pewarisan sifat manusia. BioEdu. 2(1): 77-82. 